DOI: 10.17951/lrp.2019.38.1.225-241

\author{
ZBigniew STĘPNIAK \\ Uniwersytet Warmińsko-Mazurski w Olsztynie. Wydział Nauk Społecznych, \\ Katedra Wczesnej Edukacji \\ https://orcid.org/0000-0002-6543-0875
}

\title{
LITERACKO-TEOLOGICZNO-RETORYCZNY KONTEKST SOLOWYCH KOMPOZYCJI WOKALNYCH W WYMIARZE EDUKACYJNYM
}

\begin{abstract}
Streszczenie: Autor, jako muzykolog, w swoim badaniach zajmuje się teologiczno-retoryczną analizą barokowych kompozycji wokalnych, pisanych na niski bas, oraz literackim kontekstem pieśni, które wykonuje. Jako wykonawca (bas, basso-profondo) w swoim repertuarze ma pieśni religijne i świeckie, arie operowe oraz dzieła oratoryjno-kantatowe obejmujące okres od wczesnego baroku do współczesności. Jako ksiądz katolicki często sam organizuje swoje recitale wokalne, przygotowuje słowo wprowadzające, nawiązując przy okazji do prowadzonej pracy badawczej. Koncerty te ze względu na ściśle określone grupy odbiorców (dzieci szkolne, młodzież akademicka, osoby dorosłe, w tym słuchacze Uniwersytetu Trzeciego Wieku), formę prowadzenia oraz określony repertuar, przybierają formę edukacyjną. Materiał badawczy do niniejszego artykułu stanowią programy wybranych koncertów autora, zapis nutowy wykonywanych utworów wraz z tekstami, wyniki badań własnych (publikacje) nad twórczością wybranych kompozytorów (Nowowiejskiego i Moniuszki), teologiczno-retoryczne rozprawy autora na temat niektórych wykonywanych przez niego kompozycji barokowych na niski bas. Metodę badawczą artykułu określić można jako eksplorację własnej działalności koncertowej, programów koncertów oraz sposobów ich prowadzenia, a także analizę literacką i historyczną wybranych kompozycji w szeroko pojętym wymiarze edukacyjnym uwzględniającym różne grupy wiekowe słuchaczy. Muzyka, w szczególności muzyka wokalna, ma uczyć, wychowywać, uwrażliwiać, zarówno poprzez wartości, które posiada sama w sobie, jak też poprzez kontekst religijny, literacki, historyczny czy patriotyczny. Tego chce dowieść autor, wskazując na formy edukacji w zakresie innych dziedzin (teologia, literatura, historia, wychowanie patriotyczne) poprzez własną działalność koncertową.
\end{abstract}

Słowa kluczowe: literatura, poezja, teologia, retoryka, muzyka wokalna, historia muzyki, patriotyzm 


\section{WSTEP}

Pozytywne oddziaływanie muzyki na różne sfery życia człowieka zostało dostrzeżone już w starożytności, o czym świadczy stwierdzenie Arystotelesa: „Muzyka może uszlachetniać charakter" (Arystoteles 2001, s. 219). Filozof wskazywał również na edukacyjne właściwości muzyki w zakresie kształtowania moralności czy charakterów młodzieży: „Okazuje się [...], że muzyka posiada zdolności pewnego wpływania na moralne kształcenie duszy. Jeżeli zaś może to robić, to oczywiście powinno się w niej młodzież zaprawiać i kształcić [...]. A może należy raczej przyjąć, że muzyka wpływa na cnotę, ponieważ, jak gimnastyka wyrabia do pewnego stopnia ciało, tak i muzyka może oddziaływać na charakter przez to, że przyzwyczaja radować w sposób właściwy?” (Arystoteles 2001, s. 218, 221).

Autor niniejszego opracowania, jako koncertujący śpiewak (bas, basso-profondo), rolę i znaczenie muzyki w życiu społeczeństwa i jednostki docenia w sposób szczególny. W programach realizowanych przez niego koncertów znajdują się dzieła obejmujące okres od renesansu do współczesności: arie operowe, pieśni polskie i obcego pochodzenia, romanse rosyjskie, songi musicalowe, utwory religijne różnych epok, w tym dzieła kantatowo-oratoryjne. Swoją działalność artystyczno-edukacyjną opiera na współpracy z licznymi organizacjami samorządowymi i instytucjami kultury. Koncerty najczęściej przygotowuje samodzielnie, pisząc różnego rodzaju projekty. Sam opracowuje programy koncertów, dobiera muzyków towarzyszących i przygotowuje słowo wprowadzające, przy czym nierzadko sam prowadzi całe przedsięwzięcie. Podawane na koncertach informacje mają przybliżyć słuchaczom historię muzyki, kultury, literatury, historię powszechną, w tym również historię krajów, z których pochodzą kompozytorzy czy sami wykonawcy. Celem tego typu działalności jest m.in. kształcenie i wychowywanie przez muzykę dzieci i młodzieży, ale też stwarzanie możliwości uczestnictwa w kulturze wysokiej osobom dojrzałym.

Analizując dotychczasowe doświadczenia koncertowe i badawcze nad inspiracjami tekstów literackich i biorąc pod uwagę teologiczno-muzykologiczne rozważania nad retoryką muzyczną wybranych kompozycji baroku, autor zamierza opisać edukacyjny wymiar koncertów wokalnych, a w szczególności kompozycji solowych, w zakresie przekazywania słuchaczom wiedzy na temat historii, literatury czy wybranych zagadnień teologicznych.

W kształtowaniu uczuć patriotycznych szczególną rolę odgrywają koncerty tematyczne, prezentujące twórczość tych kompozy torów, którzy byli inspirowani tekstami polskich pisarzy i poetów. Ponadto ważną sprawą jest zaszczepienie w uczestnikach koncertów umiejętności emocjonalnego i estetycznego odbioru prezentowanej muzyki, również $\mathrm{w}$ aspekcie retorycznym. 


\section{OD RECITALI WOKALNYCH DO PERCEPCJI WYBRANYCH ZAGADNIEŃ Z HISTORII POWSZECHNEJ I HISTORII MUZYKI}

Zdaniem Wiesławy Sacher, częste kontakty z muzyką powinny doskonalić u dzieci i młodzieży jej percepcję oraz rozwijać wrażliwość emocjonalną i artystyczną. Temu celowi ma służyć specyficzny sposób prowadzenia koncertów dla dzieci i młodzieży, $\mathrm{w}$ formie audycji muzycznych. Polega to na opatrywaniu wykonywanych utworów komentarzem z zakresu epoki historycznej, stylu kompozycji itp. Komentarz może być uzupełniony wzmiankami i/lub ciekawostkami z życia i twórczości danego kompozytora czy też autora tekstu. Zabiegi te mają wzbudzić zainteresowanie, skupić uwagę na przebiegu muzyki, wreszcie wywoływać u młodych słuchaczy pozytywne stany emocjonalne (Sacher 2012, s. 157-158).

Z kolei Jan Wierszyłowski twierdzi, że choć historią muzyki zajmuje się właściwie muzykologia, to jednak powinna się nią zajmować także pedagogika muzyczna i to co najmniej z trzech powodów: „Po pierwsze dlatego, że recepcja muzyczna utworu jest bogatsza lub wręcz prawidłowa, jeżeli wykorzystuje niezbędną wiedzę o utworze, po drugie - historia muzyki pogłębia rozumienie kultury muzycznej, po trzecie [...] może dać wiele korzyści z badania faktów dla muzykologii drugorzędnych, słabo badanych, a dla pedagogiki muzycznej pierwszorzędnych - dotyczących wychowania i kształcenia muzycznego z wszelkimi istotnymi dla współczesnej praktyki szkolnej szczegółami. [...] Pedagogika muzyczna, korzystając z nagromadzonych przez muzykologię danych o muzyce, powinna systematyzować je i analizować według własnych zasad i celów, przekazując sformułowane w odpowiedni sposób wnioski praktyce wychowania i kształcenia muzycznego. [...] W tym zakresie jednym z najcenniejszych źródeł wychowawczych [...] są wyczerpujące biografie muzyków, wielkich ludzi, kompletne, obiektywne bodaj $\mathrm{w}$ intencji autora, pokazujące to, co w człowieku jest najistotniejsze, co rodzi wielkość, pożyteczność i artyzm (Wierszyłowski 1977, s. 58-59).

Warto więc zadać pytanie, czy powyższe ustalenia teoretyczne i teza o edukacyjnym wymiarze muzyki znalazła potwierdzenie w dotychczasowej działalności koncertowej autora niniejszego artykułu. Odpowiedzi można udzielić w oparciu o opis i analizę kilku koncertów zrealizowanych na przestrzeni ostatnich lat.

W przekonaniu autora artykułu jeden ze scenariuszy koncertów w założeniu miał dać sposobność wykazania edukacyjnych walorów muzyki. Był to recital zatytułowany Między sacrum a profanum. Edukujmy muzyką!, zrealizowany w ramach I Międzynarodowej Konferencji Naukowej Człowiek - sztuka - edukacja (11 czerwca 2014 roku). W programie znalazło się dziewięć kompozycji religijnych i świeckich w układzie chronologicznym: od baroku do współczesności. Każdy wykonany utwór pozwolił nawiązać do konkretnych dziedzin życia i nauki, np. 
koncert wokalny na bas solo Deus in nomine Tuo Marcina Mielczewskiego nawiązywał do rozważań natury teologicznej i historii biblijnej w kontekście historii powstania słów Psalmu 53 („Boże, wybaw mnie w Imię Twoje...”), na którym kompozytor oparł swój utwór. Psalm ten napisano w obliczu trwogi Dawida przed prześladowaniami ze strony króla Saula. Z kolei pieśń Ave Maria, powszechnie przypisywana Giulio Cacciniemu, w rzeczywistości skomponowana przez Władimira Wawiłowa, stała się do okazją do przedstawienia słuchaczom sprawy błędnej atrybucji (czy też mistyfikacji) utworów muzycznych. Romans Wasilija Lipatowa Pis'mo $k$ matieri stał się okazją do zaprezentowania liryzmu rosyjskiej poezji na przykładzie utworu wybitnego poety Sergiusza Jesienina. Wykonywane na koncercie polskie pieści stanowiły niepowtarzalną okazję do prezentacji wybranych utworów polskiej i niemieckiej literatury: $W$ mojej Ojczyźnie P. Łukaszewskiego do słów Cz. Miłosza, Znasz-li ten kraj S. Moniuszki do słów Mignon J. Goethego w tłumaczeniu Mickiewicza, Dziad i baba S. Moniuszki do słów J.I. Kraszewskiego. Wykonanie songu musicalowego Gdybym był bogaczem z musicalu Skrzypek na dachu J. Bocka dało możliwość nawiązania do historii narodu żydowskiego w carskiej Rosji. Wreszcie wykonana na bis aria Skołuby Ten zegar stary z opery Straszny dwór S. Moniuszki dała sposobność nawiązywania do historii dziewiętnastowiecznej Polski.

W zamierzeniu autora, w głównej mierze właśnie cele edukacyjne, miały przyświecać kilku koncertom, które zostały przygotowane dla dzieci szkół podstawowych w Grodnie w październiku 2013 roku'. Ich tytuł brzmiał: О пюбви в опере, польской песне и русском романсе. Ich pierwotny program zawierał trzynaście utworów, w tym pięć basowych arii operowych (W.A. Mozarta, F. Halévy’ego, N. Rimskiego-Korsakowa oraz S. Moniuszki), trzy pieśni Stanisława Moniuszki oraz pięć klasycznych romansów rosyjskich (A. Borodina i P. Czajkowskiego). Na bis zaplanowano song Gdybym byt bogaczem z musicalu Skrzypek na dachu Jerry'ego Bocka. Tak skonstruowany program okazał się zbyt ambitny, ponieważ odbiorcami były dzieci w wieku 7-11 lat. Trzeba było na bieżąco wycofywać niektóre utwory, tak aby koncert przybrał formę audycji muzycznej z pogadanką o utworach, kompozytorach itp. Takie sytuacje zdarzały się niejednokrotnie, więc należało odpowiednio reagować, żeby zachować edukacyjny wymiar koncertu. W niektórych wypadkach koncerty trzeba było ograniczyć do dwóch arii operowych, dwóch pieśni Moniuszki, jednego romansu oraz bisu. Ważnym czynnikiem edukacyjnym okazało się też włączenie do aktywnego udziału w koncercie dzieci poprzez rozmowę na temat wybranych faktów $\mathrm{z}$ historii muzyki, podawanie in-

${ }^{1}$ Koncerty odbywały się w dniach 23-25.10.2013; akompaniowały pianistki z Grodna: Irina Grachowska i Natalia Radzińska. 
formacji o poszczególnych kompozytorach oraz streszczanie w języku rosyjskim polskich pieśni (dla przypomnienia: słuchaczami byli uczniowie szkół na Białorusi).

Szczegółowy program cyklu koncertów zatytułowanych $О$ любви в опере, польской песне и русском романсе dla uczniów szkół podstawowych w Grodnie wyglądał następująco (w nawiasie znakiem „+" zaznaczono utwory, które podczas dokonywania selekcji ze względu na wiek słuchaczy pozostawiono w programie większości koncertów):

1. W.A. Mozart, aria Leporella Notte e giorno faticar z opery Don Giovanni

2. W.A. Mozart, aria Sarastra O Isisund Osiris z opery Die Zauberflöte

3. F. Halevy, aria kardynała Brogni'ego Se, opressi ognor z opery La Luive

4. M. Rimski-Korsakow, pieśń Warega O skały groznyje z opery Sadko (+)

5. S. Moniuszko, aria Skołuby Ten zegar stary z opery Straszny dwór (+)

6. S. Moniuszko, Soltys

7. S. Moniuszko, Dziad i baba (+)

8. S. Moniuszko, Pieśn żeglarzy (+)

9. A. Borodin, Dla bieriegow

10. P. Czajkowski, Sriedz' szumnogo bała

11. P. Czajkowski, Ni słowa, o drug moj

12. P. Czajkowski, Ot czewo?...

13. P. Czajkowski, Nie tolko tot, kto znał... (+)

bis:

14. J. Bock, Gdybym był bogaczem - song z musicalu Skrzypek na dachu (+)

Opisane powyżej koncerty były dla autora pierwszym niezwykle ciekawym i owocnym doświadczeniem w pracy koncertowo-edukacyjnej poprzez muzykę z dziećmi szkół podstawowych. Dały one sposobność spraktykowania takiego planowania koncertów dla dzieci, aby wzbudzały one zainteresowanie, skupiały uwagę i - jak pisze W. Sacher - pozostawiały u młodych słuchaczy ślady emocjonalne (Sacher 2012, s. 157-158), a w rezultacie kształtowały i utrwalały zamiłowanie do muzyki.

Kolejnych doświadczeń edukacyjnych dostarczyła organizacja kilku koncertów tematycznych w Grodnie w 2016 r., których słuchaczami byli uczniowie college’u humanistycznego (wiek 15-18 lat). Pierwszy koncert (21 czerwca 2016 r.): Гори, гори моя звезда - между религиозной и светской музыкойㄹ, jak sugeruje tytuł, składał się z dwóch części: religijnej i świeckiej. W części religijnej między innymi przedstawiono dość rzadko wykonywane duety Stanisława Moniuszki, część świecką stanowiły mieszczańskie romanse rosyjskie. Koncert stał się okazją do

\footnotetext{
${ }^{2}$ Wystąpili w nim: Natalia Parfiłowa - sopran, Zbigniew Stępniak - bas, Irina Grachowska - fortepian.
} 
ukazania bliskości kulturowej Polaków i Białorusinów, czyli Słowian zachodnich i wschodnich. Wykonane w pierwszej części koncertu utwory Moniuszki, kompozytora, który tworzył na styku trzech kultur - polskiej, białoruskiej i litewskiej - dały okazję przybliżenia słuchaczom postaci tego twórcy, ale także zapoznania z liturgią Kościoła Katolickiego i jego łacińskimi modlitwami, z których kompozytor czerpał pisząc wspomniane duety. Druga część koncertu dała sposobność zaprezentowania sześciu romansów w interpretacji Polki mieszkającej od urodzenia w Grodnie (N. Parfiłowa) i Polaka urodzonego w Olsztynie (Z. Stępniak). W tej części słuchacze mieli możność poznać twórczość wielkich rosyjskich poetów.

Drugi koncert dla młodzieży college'u humanistycznego w Grodnie (w październiku 2016 r.), zatytułowany Не пробуждать воспоминаний, miał charakter solowego recitalu $\mathrm{z}$ towarzyszeniem fortepianu (Z. Stępniak i I. Grachowska) i składał się z dwóch części: polskiej i rosyjskiej. W pierwszej zaprezentowano pieśni S. Moniuszki oraz współczesnego kompozytora polskiego Pawła Łukaszewskiego. Część ta umożliwiła ponowne przybliżenie słuchaczom postaci wybitnego polskiego twórcy Moniuszki, zapoznanie z twórczością Łukaszewskiego, ale też ze znanymi poetami polskimi, takimi jak np. Adam Mickiewicz czy Czesław Miłosz. Druga część koncertu, na którą składały się klasyczne i mieszczańskie romanse rosyjskie, była właściwie przypomnieniem tego, co słuchacze znają i co nie wymagało obszernego komentarza. Taki scenariusz koncertu utwierdził autora w przekonaniu, że program należy tak konstruować, aby z jednej strony uczył i rozwijał, z drugiej zaś wzbudził zainteresowanie, wywołał dobre emocje i nie znużył słuchaczy. Te dwa aspekty: edukacyjny i rozrywkowy muszą się ze sobą łączyć i nawzajem przenikać. Stworzenie takiego stanu rzeczy stanowi podstawę osiągnięcia założonych celów.

Ciekawym doświadczeniem w działalności wokalnej autora był koncert $\mathrm{Om}$ любви к Богу, по любовь к людям, który odbył się w kościele katedralnym w Irkucku (początek października 2016 r.). Odbiorcami byli przeważnie ludzie dorośli. Koncert miał na celu zapoznanie mieszkańców Irkucka z wybranymi utworami muzyki europejskiej. W programie znalazły się pochodzące z różnych epok utwory sakralne i świeckie, w tym kompozycje S. Moniuszki i P. Łukaszewskiego. Koncert prowadził, ale też akompaniował soliście na organach i fortepianie, katedralny organista Deczebał Grigoruce. Nawiasem mówiąc jego rola w tym koncercie była szczególna. Oprócz akompaniowania zapowiadał poszczególne utwory, charakteryzował epokę, w której powstały, podawał informacje o kompozytorach i autorach tekstów. Ponadto teksty polskie tłumaczył na język rosyjski, co niewątpliwie znacznie ułatwiło odbiór koncertu rosyjskojęzycznym słuchaczom.

Wymiar szczególny w zakresie edukacji z dziedziny historii powszechnej, w tym historii muzyki, dla różnych grup wiekowych, miały recitale, w których program 
był ułożony chronologicznie: od epoki późnego renesansu do współczesności. Tego typu koncerty były realizowane zarówno w kraju, jak i za granicą, np.:

- Od Zieleńskiego do Lukaszewskiego - koncert muzyki polskiej,

- Vom gregorianischen Choral bis zur Gegenwart - recitale muzyki sakralnej w Szwajcarii,

- Od Monteverdiego do Łukaszewskiego - koncerty w Polsce, Von Monteverdi bis Moniuszko - koncerty w Szwajcarii,

- Zwischen dem Alten und dem Neuen. Konzert der Kirchenmusik - recitale w Szwajcarii,

- Od baroku do współczesności - koncerty w Polsce,

- Молю Тебя, создатель мой - koncert sakralny w Nowosybirsku,

- Oper - Musical - Romanze - Volksmusik - Opernarien, Musikal-Songs, Russische Romanzen, Jazz-Standards, Volksmusik - recitale w Szwajcarii. Znaczny potencjał edukacyjny posiadały także recitale tematyczne, m.in. dały sposobność przybliżenia historii poszczególnych gatunków muzycznych, np.

- Muzyka zza oceanu - koncert pieśni musicalowych,

- Pieśni pisane cyrylica - koncert pieśni i romansów rosyjskich,

- W barokowym nastroju,

- Polskie - najpiękniejsze - koncert muzyki kompozytorów polskich,

- Swiat opery - arie ze znanych oper,

- Ze śpiewnika domowego - pieśni Stanisława Moniuszki,

- Zwischen deutscher und russischer Musik (koncerty w Szwajcarii),

- Na granicy ze Wschodem - znane pieśni polskie i rosyjskie w polsko-białoruskiej interpretacji (koncerty w Polsce),

- Modlitwa - Prayer - Gebet - Молитвa - Ima - modlitewne pieśni i duety.

Jak pisze Alina Górniok-Naglik, „Kontakt ze sztuką stanowi istotny czynnik samowiedzy i autokreacji, jest narzędziem poznawania i przetwarzania świata" (Górniok-Naglik 2007, s. 106). Wprawdzie autorka mówi o sztuce jako środku pozwalającym na spełnienie własnego człowieczeństwa, wydaje się jednak, że przytoczone powyżej przykłady kontaktów ze sztuką muzyczną, których doświadczyli słuchacze różnych grup wiekowych na opisanych powyżej koncertach, dają właśnie możliwość poznawania i kreowania świata. A słowo zaczerpnięte $\mathrm{z}$ historii muzyki powinno pokazać to, co w „człowieku jest najistotniejsze, co rodzi wielkość, pożyteczność i artyzm” (Wierszyłowski 1977, s. 59). 


\section{EDUKACYJNY WYMIAR KONTEKSTU LITERACKIEGO WYKONYWANYCH PIEŚNI SOLOWYCH}

Z obserwacji Ewy i Mirosława Kowalskich wynika, że „Od nauczycieli wymaga się już nie tylko przekazywania uczniom wiedzy i kształtowania ich umiejętności oraz postaw, lecz również takiego organizowania struktury treści kształcenia, by przedstawiały one rzeczywistość w sposób całościowy. Wartość takiej edukacji polega przede wszystkim na tym, że wiążąc w sposób nierozdzielny różne aspekty wiedzy, respektuje ona naturalny charakter procesów poznawczych, dzięki którym otaczający nas świat percypujemy zawsze jako określoną całość". Taka koncepcja „integracji” ma pozwolić na ukazanie słuchaczom „bogactwa kultury rodzimej w jej historycznym rozwoju i w ciągłości z poprzednimi pokoleniami”. Ma to na celu umożliwienie "połączenia wiedzy na temat wartości z elementami przeżycia emocjonalnego i kreatywnego wyrażania, co jest niezbędnym warunkiem kształtowania postaw wobec ojczyzny małej i wielkiej”. Dodać należy, że „poczucie tożsamości narodowej kształtuje się zawsze w odniesieniu do kultury innych narodów, bowiem identyfikacja tych wartości, które uznajemy za «nasze», jest możliwa tylko wtedy, gdy potrafimy je wyodrębnić spośród całości dorobku cywilizacyjnego, z którym mamy do czynienia”. Wynika stąd potrzeba takiego organizowania wiadomości i doświadczeń słuchaczy, „by w sposób świadomy potrafili odróżnić kulturę polską od obcej" (Kowalska, Kowalski 2002, s. 393-394).

Autor niniejszego artykułu takie cele również sobie wyznacza, przygotowując różnorodne koncerty wraz z komentarzem do poszczególnych utworów, informacje o kompozytorach i ich epoce. Zazwyczaj też nawiązuje do kontekstu literackiego wykonywanych pieśni solowych. Koncerty stwarzają okazję do prowadzenia edukacji historycznej, o czym wcześniej już pisano, ale też edukacji literackiej, przybliżają postaci twórców literatury zarówno polskiej, jak i światowej. Dają zatem możliwość kształtowania w słuchaczu poczucia tożsamości narodowej, szacunku do kultury innych narodów.

Jeden z wyżej wymienionych koncertów zatytułowany Polskie - najpiękniejsze (koncert muzyki kompozytorów polskich - Olsztyn, 1.06.2010) pozwolił przypomnieć słuchaczom postaci polskich kompozytorów, takich jak Fryderyk Chopin, Stanisław Niewiadomski, Mieczysław Karłowicz, Stanisław Moniuszko czy Feliks Nowowiejski. Pozwolił też nawiązać do życiorysów poetów, których utwory przyniosły natchnienie muzykom, m.in. Czesława Jankowskiego, Adama Mickiewicza, Ludwika Władysława Franciszka Kondratowicza (pseud. Władysław Syrokomla), Marii Konopnickiej, Józefa Korzeniewskiego, Wincentego Pola, Kazimierza Przerwy-Tetmajera, Stefana Witwickiego, Włodzimierza Wolskiego, i poetów niemieckich, takich jak Heinricha Heinego i Johanna Wolfganga von Goethego. 
Autor artykułu dał co najmniej kilkanaście koncertów romansów rosyjskich, np. jeden z nich (Olsztyn, 10.09.2015) stał się w całości okazją do przybliżenia postaci autorów słów - znanych i mniej znanych poetów rosyjskich, takich jak Wasyl Czujewski, Michaił Lermontow, Aleksander Puszkin, Nestor Kukolnik, Iwan Turgieniew, Siergiej Jesienin, Nikołaj von Ritter. Uczestnikami koncertu byli przeważnie słuchacze Uniwersytetu Trzeciego Wieku, ale także studenci Uniwersytetu Warmińsko-Mazurskiego w Olsztynie. Dla starszego pokolenia, obok przypomnienia najbardziej znanych romansów rosyjskich (Гори, гори, моя звезда і Не пробуждай воспоминанья Piotra Bułachowa oraz napisanych do słów znakomitego poety S. Jesienina - Клён ты мой опавщий..., Отговорила роща золотая..., Писмо кматери), koncert stworzył okazję do poznania wybranych utworów rosyjskiej literatury pięknej.

$\mathrm{Z}$ wielu względów, m.in. z powodu wyjątkowych walorów edukacyjnych tekstów pieśni, szczególne miejsce w działalności koncertowej autora artykułu zajmują kompozycje S. Moniuszki. Twórczość kompozytorska wybitnego Polaka stanowi skarbnicę kultury i literatury polskiej, a na szczególną uwagę zasługuje różnorodność gatunkowa i literacka Śpiewnika domowego tego wybitnego kompozytora. W 12 tomach Śpiewnika... znajdziemy romanse i ballady, lirykę miłosną i pieśni dramatyczne, śpiewy i dumy historyczne, piosnki sielskie i dumki, a także piosenki taneczne i wojenne. Rysuje się więc kolejna możliwość ujęcia historii muzyki w połączeniu z historią literatury pięknej, w nawiązaniu do historii Polski, szczególnie okresu rozbiorów i walk niepodległościowych. Urodzony na kresach wschodnich Rzeczpospolitej Moniuszko, komponując pieśni do Śpiewnika domowego, sięgnął po teksty aż 97 twórców (korzystał także z innych źródeł, np. tekstów liturgicznych i Pisma św.). W licznym gronie poetów znaleźli się głównie współcześni kompozytorowi poeci polscy, w tym tak wybitni, jak A. Mickiewicz (21 tekstów), W. Syrokomla, J. Czeczot, W. Odyniec, J.I. Kraszewski, S. Witwicki, T. Lenartowicz, ale też J. Kochanowski i wielu innych. Znacznie rzadziej kompozytor sięgał po teksty poetów zagranicznych (20 poetów obcego pochodzenia). W ogólnej liczbie 364 pieśni i duetów 40 stanowią utwory skomponowane do tekstów autorów z zagranicy. Są nimi: Anglicy (W. Szekspir, W. Scott, G. Byron), Rosjanie (W. Benediktow, I. Kozłow, N. Kukolnik), poeci francuscy (m.in. P.-J. de Béranger, C. Delavigne, V. Hugo), przedstawiciele niemieckiego romantyzmu (J.W. von Goethe i H. Heine), poeta białoruski (W. Dunin-Marcinkiewicz) i inni (Stępniak 2017, s. 383-387). Koncerty pieśni Moniuszki stwarzają możliwość ponownego przeżywania piękna i wartości zawartych w polskiej poezji, ale też kształtowania poczucia tożsamości narodowej.

W dorobku koncertowym autora można znaleźć również recitale, w których recytacje poezji stawały się integralną częścią występów. Do takich można zaliczyć: 
- koncert Na żotnierska nute - pieśni patriotyczne (Olsztyn, 25.11.2011), który dał sposobność prezentacji poezji patriotycznej, nawiązującej do zrywów narodowych XIX i XX wieku (wiersze następujących poetów: I. Krasickiego, W. Bełzy, K. Makuszyńskiego, J. Lechonia, K.I. Gałczyńskiego, T. Różewicza, J. Pietrzaka, M. Sulimy),

- koncert zatytułowany Zatrzymaj się na chwilę... - pieśni religijne kompozytorów różnych epok, który dał sposobność prezentacji poezji pochodzącego z Mrągowa kapłana-poety ks. Norberta Bujanowskiego w recytacjach samego autora.

Nie tylko zatem od nauczycieli powinno się wymagać przekazywania wiedzy, kształtowania umiejętności oraz postawy patriotycznej czy takiego organizowania struktury treści kształcenia, by przedstawiały one rzeczywistość w sposób całościowy, ale od wszystkich, którzy taki wpływ na społeczeństwo mogą i powinni mieć, a zatem także od artystów. Autor może pokusić się o stwierdzenie, że przynajmniej w pewnym stopniu udaje mu się, poprzez swoje recitale i ich prowadzenie, ukazać słuchaczom bogactwo ojczystej kultury w jej historycznym rozwoju, połączyć wiedzę z elementami przeżycia emocjonalnego i kreatywnego wyrażania, kształtować poczucie tożsamości narodowej w kontekście kultury innych narodów.

\section{KONCERTY PIEŚNI PATRIOTYCZNYCH A EDUKACJA HISTORYCZNO-PATRIOTYCZNA}

Obchody 100-lecia odzyskania przez Polskę niepodległości dały wiele okazji do prowadzenia edukacji historyczno-patriotycznej, także poprzez działalność koncertową. Padło wiele słów o konieczności powrotu do tradycji, obyczajów, do przeszłości, jako wartości nadrzędnych. „Szczególnie mocno identyfikujemy się z przeszłością. Czasy minione są bowiem siedliskiem chwały i zaszczytu, ale też smutku i rozpaczy. Niestety w pamięci potomnych przeważa ten smutny obraz dziejów naszej Ojczyzny. Najbardziej emocjonalnie podchodzą Polacy do dwóch ostatnich stuleci, kiedy to Naszej Ojczyzny nie było na mapach Europy w ogóle, lub istniała, ale tylko teoretycznie (jak po kongresie wiedeńskim czy w okresie socjalizmu)" (Gołąb, Sroka, Słomiński 2017, s. 94).

Konrad Hennig zwraca uwagę, że „Prowadzenie polityki historycznej znajduje się w żywotnym interesie naszego państwa. Patriotyzm bowiem ma swoje wymierne, funkcjonalne znaczenie. Przesądza o obywatelskim morale, które określa gotowość do wystawienia na ryzyko własnego życia w sytuacji zagrożenia i nie mniej ważną gotowość do pozbawienia życia najeźdźców. W przypadku życia rodzinnego taką gotowość wzbudza w nas miłość, to ona uzasadnia użycie 
wszelkich dostępnych środków dla obrony najbliższych. Dla wspólnoty politycznej tym uczuciem umiłowania ojczyzny jest patriotyzm, dlatego powinien on być pieczołowicie pielęgnowany przez decydentów i elity społeczne. Deficyty morale obywateli bywają zgubne dla państwa" (Hennig 2017, s. 10-11).

Treści powyższych cytatów nasuwają refleksję, że warto powracać do patriotyzmu „wyśpiewywanego" podczas koncertów i artykułowanego w tzw. słowie wprowadzającym do nich. W działalności koncertowej autora artykułu można wyróżnić kilka koncertów o charakterze patriotycznym, np. Na żołnierską nutę ${ }^{3}$. W programie znalazły się pieśni F. Chopina (Wojak, Leci liście z drzewa), S. Moniuszki (Stary kapral, Piosnka żołnierza, Sołtys), pieśni patriotyczne z różnych okresów historii: Warszawianka K. Kurpińskiego (1830-1831), Witaj, majowa jutrzenko (1830-1831), Rota M. Konopnickiej i F. Nowowiejskiego (1908), Przybyli ułani (1914), pieśń I Brygady Legionów Polskich (1914), Czerwone maki na Monte Cassino (1944). Układ chronologiczny wykonywanych podczas koncertu utworów można zinterpretować jako „swoistą lekcję” historii Polski.

Podobną sposobność dał koncert zatytułowany: Pieśni Wolności. Koncert niepodległościowy, który miał miejsce 11 listopada 2016 r. w Filharmonii w Gorzowie Wielkopolskim (dyr. F. Suwała, Orkiestra Filharmonii Gorzowskiej, Beata Gramza - sopran, Zbigniew Stępniak - bas, basso-profondo). W programie znalazły się pieśni i utwory patriotyczne w aranżacji orkiestrowej emerytowanego pułkownika Wojska Polskiego i długoletniego dyrygenta orkiestr wojskowych Franciszka Suwały.

Z okazji 550-lecia włączenia Warmii do Polski 16.11.2016 r. ${ }^{3}$ w Olsztynie odbył się specjalny koncert. W części patriotycznej recitalu przypomniano, a zarazem uczczono, najtrudniejsze wydarzenia w historii naszej Ojczyzny: Pożegnanie (Bywaj dziewcze zdrowe) (Powstanie Listopadowe, 1830-31), W krwawym polu srebrne ptasze (Powstanie Styczniowe, 1863), Marsz Pierwszej brygady (I wojna światowa, 1914-1918), Czerwone maki na Monte Cassino (II wojna światowa, bitwa pod Monte Cassino w 1944 r.).

W tekstach pieśni polskich kompozytorów odnajdujemy słowa inspirowane różnymi zrywami narodowymi, np. do takich należy pieśn F. Chopina do słów Wincentego Pola Leci liście z drzewa, opisująca Polskę przedrozbiorową (nawiązanie do konfederacji targowickiej z 1792 roku).

Jak stwierdzono we wstępie do tej części artykułu, czasy minione są dla Polaków zarówno powodem do chwały i dumy z naszej Ojczyzny, ale też smutnych refleksji. Patriotyzm równoznaczny z uczuciem umiłowania ojczyzny powinien być pieczołowicie pielęgnowany nie tylko z urzędu, ale również przez artystów

${ }^{3}$ Listopad 2010 r. Wykonawcy: ks. Zbigniew Stępniak - śpiew, słowo o muzyce, recytacja poezji patriotycznej, Lucyna Żołnierek - fortepian. 
i całe polskie społeczeństwo. Uczyć się tego uczucia trzeba na pozytywnych przykładach działań naszych przodków, jak i oceniając popełnione w historii naszej Ojczyzny błędy.

Artyści, moim zdaniem, są szczególnie predystynowani, żeby pełnić misję edukacyjną w zakresie kształtowania i pielęgnowania uczuć patriotycznych narodu.

\section{PRZEZ RETORYKĘ MUZYCZNĄ BAROKU DO TEOLOGII I KATECHEZY}

Łącząc w swojej działalności praktykę badawczą (jako muzykolog) i wykonawczą (jako śpiewak) autor sugeruje możliwość wykorzystania muzyki w nauczaniu teologii czy po prostu w nauce religii.

W przypadku utworów obcojęzycznych można intuicyjnie zrozumieć, o czym śpiewa chór lub solista. Istnieją zabiegi muzyczne, szczególnie te, mające swoje korzenie w retoryce muzycznej baroku, które wyraźnie wskazują na treści wykonywanego utworu, np. w Credo (części wielkiej mszy koncertującej) kompozytor najczęściej podkreśla słowa o wniebowstąpieniu Chrystusa wznoszącą się linią melodyczną, z kolei treść o „zstąpieniu do piekiel” jest wyrażana linią melodyczną opadającą. Zmiana metrum (w Credo) z dwudzielnego na trójdzielne (tzw. metrum doskonałe) może sugerować, że jest mowa o Trójcy Przenajświętszej (retoryczna i biblijna symbolika liczb).

Ze swoich badań retoryczno-teologicznych autor chciałby przytoczyć kilka przykładów łączenia kontekstu teologicznego tekstów i retorycznego znaczenia linii melodycznej podkreślającej dramaturgię tekstu słownego.

Wspomniana już figura wznoszącej się linii melodycznej nosi nazwę anábasis (ascensus) i jest muzycznym odcinkiem, który wskazuje na rzeczy wzniosłe, wybitne (Bartel 1985, s. 84). W wykonywanym przez autora artykułu koncercie Singet dem Herrn Johanna Philipa Kriegera odnajdujemy co najmniej dwa odcinki podkreślające rzeczy i zjawiska wzniosłe. Czynnością wzniosłą jest śpiewanie na chwałę Boga (singet dem Herrn). Figurą anábasis wprowadza solowy głos basowy pierwsze słowa koncertu: singet dem Herrn („śpiewaj Panu;” przykład 1). Ten sam zabieg muzyczny eksponuje również słowa erzählet unter den Heiden („rozpowiadajcie pośród pogan”; przykład 2). Wydaje się, że takim wyniesieniem dla narodów pogańskich będzie uznanie chwały Boga jedynego (Stępniak 2015c, s. 214-215). 


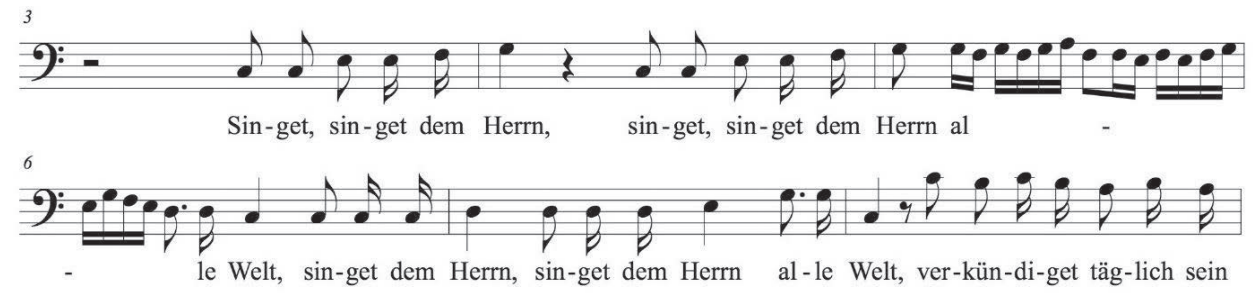

Przykład 1. Koncert Singet dem Herrn Johanna Philipa Kriegera (t. 3-4)

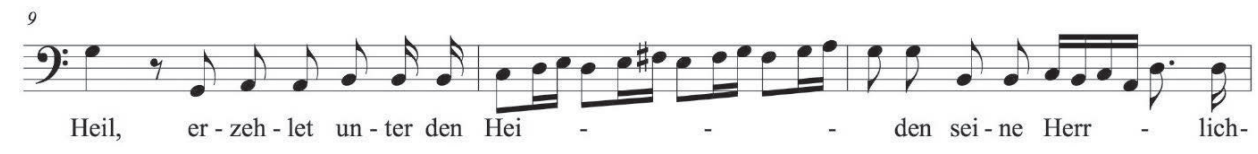

Przykład 2. Koncert Singet dem Herrn Johanna Philipa Kriegera (t. 9-11)

Figura retoryczna, w której melodia zstępuje w dół nosi nazwę katábasis (descensus - schodzenie, zstępowanie). Ton opadający linii melodycznej wskazuje na uniżenie, marność, pokorę, smutek czy nawet przygnębienie (Jasiński 2009, s. 293). W motecie Ab aeterno ordinata sum Claudio Monteverdiego znajdujemy co najmniej dwa miejsca, w których kompozytor zastosował tę figurę. Kiedy Bóg „szykował niebiosa do bytu” (quando pae parabat caelos ad eram) kompozytor zejście to podkreśla właśnie figurą katábasis połączoną z circulatio (oznaczającą niepewność, wahanie się), „kiedy właściwe prawa i kierunki wód ustalał” (quando certa legge et gyro vallabant abyssos), kompozytor trzykrotnie stosuje tę figurę, rozpoczynając ją od górnych możliwości głosu basowego i wykraczając wręcz poza skalę przeciętnego basu w dolnych jego partiach (słowo abyssos - przepaść, głębia) (Stępniak 2015a, s. 146-147).

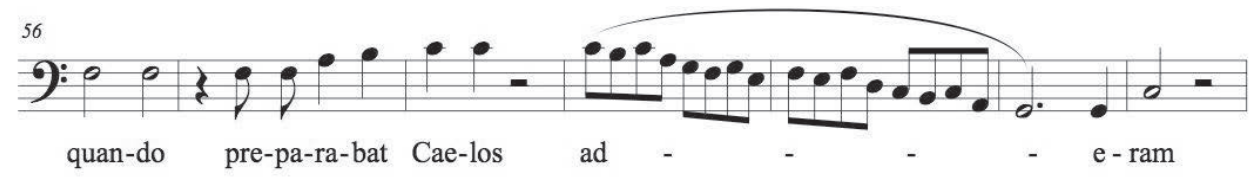

Przykład 3. Motet Claudio Monteverdiego Ab aeterno ordinata sum (t. 56-62) 

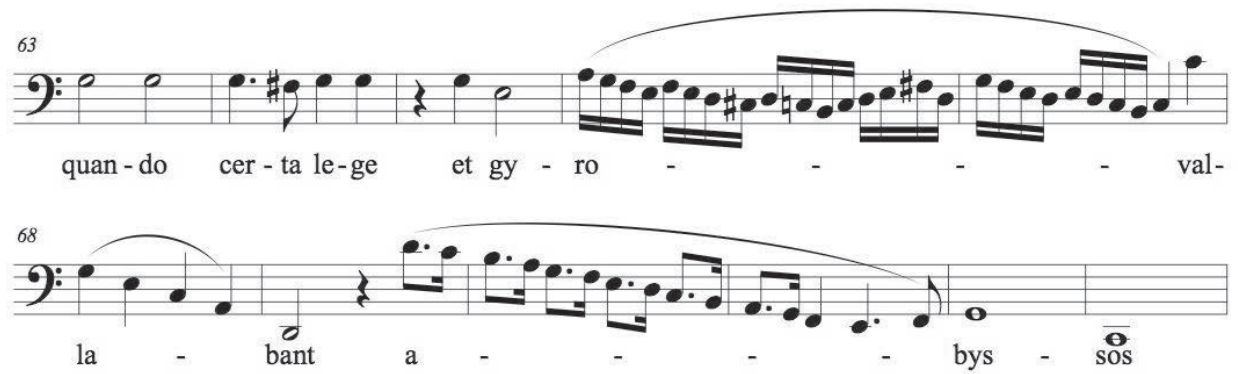

Przykład 4. Motet Claudio Monteverdiego Ab aeterno ordinata sum (t. 63-73)

W tym samym utworze Monteverdiego można wskazać figurę kýklosis (circulatio - krążenie), oznaczającą stan pośredni pomiędzy anábasis a katábasis. Jak już wcześniej wspomniano, wskazuje ona na niepewność, niezdecydowanie, wahanie czy bojaźń (Jasiński 2009, s. 293). Dźwiękowe malarstwo żywiołów oddają figury circulatio zastosowane na słowach flumina (rzeka) czy mari (morze). Zabieg ten może też podkreślać niezdecydowanie, niepewność albo wprost kręte ścieżki życia człowieka (Stępniak 2015a, s. 146-147).

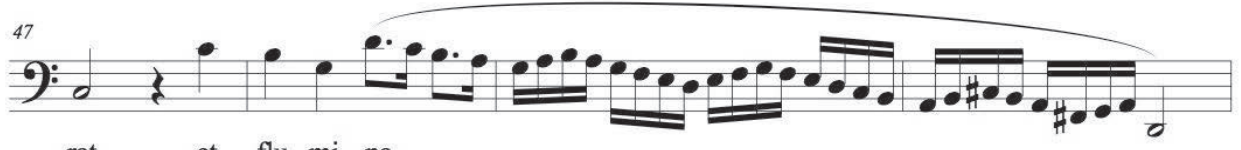

rat et flu-mi-na

Przykład 5. Motet Claudio Monteverdiego Ab aeterno ordinata sum (t. 47-50)

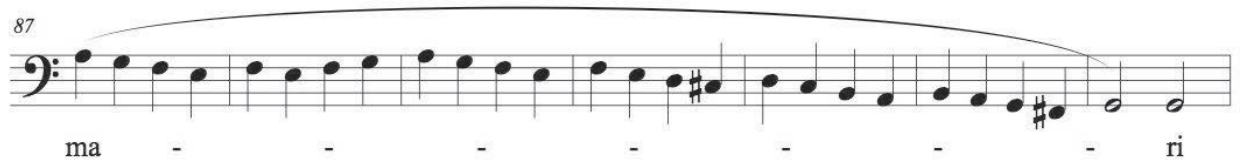

Przykład 6. Motet Claudio Monteverdiego Ab aeterno ordinata sum (t. 87-93)

Przerywanie dźwięków pauzami dla oddania westchnienia, płaczu, tęsknoty, to figura tmesis (suspiratio) (Jasiński 2009, 330). Taką figurę autor odnajduje w wykonywanym przez siebie koncercie kościelnym Jubilate Deo Johanna Valentina Medera. Kompozytor zastosował ją na słowie confitemini (stawajcie) kończącym fragment czwarty dzieła. Stawać przed obliczem Boga można nie tylko z niepewnością, ale i z tęsknotą (Stępniak 2015b, s. 142). 


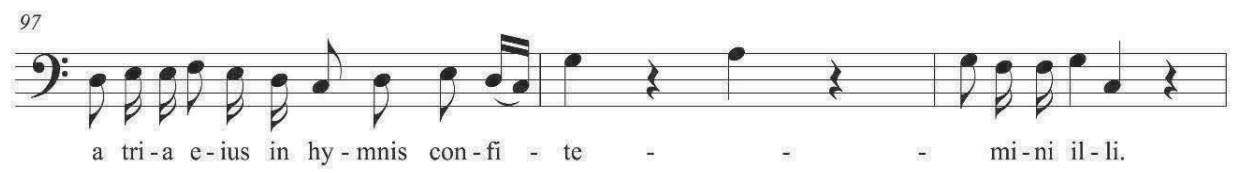

Przykład 7. Johann Valentin Meder, Jubilate Deo, takty 97-99

\section{PODSUMOWANIE}

Dotychczasowa działalność koncertowa autora niniejszego opracowania oraz zdobyte doświadczenia pozwalają stwierdzić, że muzyka daje ogromne możliwości edukacyjne. Pozwala uczyć, wychowywać, uwrażliwiać, zarówno poprzez wartości, które posiada sama w sobie, jak też poprzez kontekst religijny, literacki i historyczny. Artyści są szczególnie predystynowani, żeby pełnić misję edukacyjną także w zakresie kształtowania i pielęgnowania uczuć patriotycznych narodu. Ważną potrzebą jest też zaszczepienie w uczestnikach koncertów umiejętności emocjonalnego i estetycznego odbioru prezentowanej muzyki.

Artystę, który włącza do swojej działalności koncertowej wątki edukacyjne zazwyczaj cechuje pasja, bo ona może stanowić podstawę sukcesu i siłę sprawczą działania.

\section{LITERATURA}

Arystoteles, 2001, Polityka - Księga VIII. W: Arystoteles, Dzieła wszystkie, tom 6 (Polityka, Ekonomika, Retoryka, Retoryka dla Aleksandra, Poetyka, Zachęta do filozofii, Ustrój polityczny Aten, List do Aleksandra Wielkiego, Testament). przekł. Ludwik Piotrowicz. Warszawa, Wydawnictwo Naukowe PWN, 214-225.

Bartel D., 1985, Handbuch der musikalischen Figurenlehre. Laaber, Laaber-Verlag. Gołąb A., Sroka J., Słomiński K., 2017, Różne oblicza wychowania patriotycznego. Tradycja czy alternatywa?. W: K. Henning (red.), Wychowanie patriotyczne. Pedagogika - polityka bezpieczeństwa - polityka historyczna. Łódź, Wydawnictwo Akademii Humanistyczno-Ekonomicznej w Łodzi, 93-107.

Górniok-Naglik A., 2007, W dialogu sztuki z edukacją. Toruń, Wydawnictwo Edukacyjne „AKAPIT”.

Hennig K., 2017, Słowo wstępu. W: K. Henning (red.), Wychowanie patriotyczne. Pedagogika - polityka bezpieczeństwa - polityka historyczna. Łódź, Wydawnictwo Akademii Humanistyczno-Ekonomicznej w Łodzi, 7-12. 
Jasiński T., 2009, Polska barokowa retoryka muzyczna. Lublin, Wydawnictwo Polihymnia.

Kowalska E., Kowalski M., 2002, Kształtowanie poczucia tożsamości narodowej na

lekcjach muzyki. W: L. Kataryńczuk-Mania, J. Karcz (red.), Wybrane zagadnienia edukacji artystycznej dzieci i młodzieży. Zielona Góra, Oficyna Wydawnicza Uniwersytetu Zielonogórskiego, 391-395.

Sacher W.A., 2012, Pedagogika muzyki. Teoretyczne podstawy kształcenia muzycznego. Kraków, Oficyna Wydawnicza „Impuls”.

Stępniak Z., 2015a, The theology of the Old Testament Book of Proverbs (Prov. 8:23-31)

in the "Ab aeterno ordinata sum" solo motet for basso profundo by Claudio Monteverdi. W: A. Grabowski, M. Suświłło (red.), Art in the public and sacred spheres. Olsztyn, Wydawnictwo UWM, 137-155.

Stępniak Z., 2015b, Teologia Psalmu 100 (99) a muzyczna retoryka baroku $w$ koncercie Johanna Valentina Medera (1649-1719) „Jubilate Deo”. W: J. Jemielnik, J. Posłuszna (red.), Muzyka i refleksja pedagogiczna. Perspektywy - interpretacje - pogranicza. Kraków, Wydawnictwo Aureus, 131-148.

Stępniak Z., 2015c, Teologia starotestamentalnej pieśni pochwalnej Śpiewaj Panu cała ziemio (1 Krn 16, 23-34) a barokowa retoryka muzyczna w kantacie Singet dem Herrn alle Welt na bas solo, dwie trąbki i b.c. Johanna Philippa Kriegera (1649-1725). W: E. Kochanowska, R. Majzner (red.), Muzyka w dialogu z edukacja. Wybrane konteksty aktywności i edukacji muzycznej. Kraków, Wydawnictwo Libron, 205-221. Stępniak Z., 2017, Na kulturowej granicy Polski i Białorusi - inspiracje literackie $i$ wartości artystyczne „Śpiewnika domowego” Stanisława Moniuszki. „Studia Wschodniosłowiańskie", t. 17, 379-392.

Wierszyłowski J., 1977, Specyfika pedagogiki muzycznej. Warszawa, Wydawnictwa Uniwersytetu Warszawskiego.

LITERARY, THEOLOGICAL AND RHETORICAL CONTEXT OF SOLO VOCAL COMPOSITIONS IN THE EDUCATIONAL DIMENSION

\begin{abstract}
In this research, the author as a musicologist performs a theological and rhetorical analysis of baroque vocal compositions written for low bass and studies the literary context of the songs that he performs. The author is a performing artist (bass, basso profondo) and his repertoire includes songs (both religious and secular), opera arias, oratorios and cantatas by composers of the periods ranging from early baroque to contemporary. As a Catholic priest he often personally organises his vocal recitals, prepares introductory speeches taking the opportunity to make reference to the conducted research. These concerts, often due to strictly specified target audience (schoolchildren, university students, adults, including students of
\end{abstract}


the University of the Third Age), form of presentation and specified repertoire, have a sensu stricto educative form. The research material hereof consists of programs of the selected concerts performed by the author, the musical scores of the performed pieces with their texts, results of the author's own research (publications) on the oeuvre of the selected composers (Nowowiejski and Moniuszko), theological and rhetorical dissertations of the author on baroque compositions for low bass performed by him. The research method of the article may be described as exploration of the author's own concert activity, concert programs, the way of holding concerts and literary and historical analysis of the selected compositions in broadly understood educational dimension taking into account various age groups of the audience. Music, including in particular vocal music, is aimed at teaching, educating, raising awareness, by both the values that it holds as such and by its religious, literary, historical and patriotic context. This is what the author tries to prove, indicating the forms of education with other disciplines (theology, literature, history, patriotic education), with his own concert activity.

Key words: literature, poetry, theology, rhetoric, vocal music, music history, patriotism 